\title{
https://doi.org/10.5817/NR2018-2-7
}

\section{Spor jako jádro literatury a několik otázek}

OLASZEK, B.: Русские споры в художественном дискурсе классиков. Łódź: Wydawnictwo Uniwersytetu Łódzkiego, 2016. ISBN 978-83-8088-136-5.

Když Michail Bachtin kdysi založil svou koncepci románů Dostojevského na tezi o dialogu, resp. vícehlasosti, polyfonii, později někteří badatelé tvrdili, že jeho inspirací bylo i reálné společenské podloží mnohonárodní Ruské říše, resp. SSSR. Upozornilo se tak na možné specifikum Rusů a Ruska jako takových, na jejich sklon k diskusi, polemice, sporům a debatám či disputacím. Sám materiál ruské literární klasiky nám $\mathrm{k}$ tomu dává dostatek př́kladů, zejména $\mathrm{v}$ subžánru tzv. ideologické besedy, jak ji známe nejen z Dostojevského, ale i z Tolstého, Turgeněva nebo Čechova a dalších „klasikư“, a to jsou ostatně klíčové postavy knížky. Jiná je ovšem struktura a funkce těchto disputací, které kdysi vedly k popularitě ruského románu ve světě: tak to viděli evropští čtenáři, tedy i Češi, později však vedly spíše k odmítání ruské literatury (po roce 1920) jako př́liš didaktické, nudné, charakterologické apod.

Polská rusistka z Lodže se ujala problematiky, která je sice nápadná, ale v původním uchopení může vskutku odhalit leccos neznámého nebo méně známého. Teoretický základ probírá autorka hned na počátku a opírá se přitom o ruské teoretiky komunikace, vedení sporu, debat. ${ }^{1}$ Nicméně vzniká z toho pocit, že jde jen o jinými slovy vyjádřené pojmy, jako jsou nihilistický, antinihilistický a publicistický román ve vztahu k 6o.-70. letům 19. století spojeným s revolučními demokraty a narodniky, tedy s diskusemi ruských radikálních pozitivistů a přivrženců „chození mezi lid“, kteří reagovali na podněty západniků a slavjanofilů. To, co je podstatné, je, že Olaszek vnáší do svého diskursu silný generační princip (kapitola III.), jak jej vyznávali kdysi i Rusové, ale potom ho poněkud potlačili: to je problém depresí romantiků druhé vlny (Lermontov), ale také zklamání postromantiků, z nichž se stávali počínající realisté (jak je vidět v Gončarovových románech Všední prǐběh a Strž). Spor vidí jako výstavbový princip již v hořké komedii A.S. Gribojedova Hoře z rozumu - tomu však poněkud protiřečí Gončarovova recenze Milión trápení (Мильон терзаний). I monologický román obsahuje spory: takové jsou v románech Ivana Turgeněva (Rudin, Otcové a děti, později Dým a Novina). Autorka přebírá pojem polemický román a prodírá se houští textů 6o.-70. let 19. století: zde jsem poněkud zklamán, nebot jsem čekal, že půjde o zkoumání typologie sporu a dialogu a žánrové utváření, ale to se nestalo. To se markantně projevilo v analýzách tzv. antinihilistického románu Pisemského

1 Např. [POVARIN 2009]; důležitý pojem „polemický román“ v knize N. N. Staryginové: [STARYGINA 2003]. 
a Leskova, zejména nejlepšího z nich (Slepá ulička / Není kam jít - Někuda). Ty jsem kdysi zkoumal právě s ohledem na konflikt dramatického a kronikového principu v knihách a statích o Leskovovi a románové kronice. ${ }^{2}$ Nemyslím, že trochu mechanické převzetí Bachtinova dělení románu na monologický a polyfonický a do nich vklíněný polemický bylo zdařilé a to je škoda ${ }^{3}$ : autorka mohla právě využitím „anatomie a fyziologie" sporu ukázat ze zcela jiné strany stavbu a fungování románového tvaru a zcela jinak než sám Bachtin. Proto také takový pohled na romány Dostojevského ve spojitosti se sporem vedl poněkud do slepé uličky. Zajímavější jsou v tomto smyslu výklady A. Čechova. Pokud jde o závěry (Itogi), nemyslím, že by byl tak markantní rozdíl mezi sporem v románech monologických a románech Dostojevského; vždy jde o spor ideologický, jakkoli „věčně“ se tváří nebo právě proto. Kapitola pátá pojednává o sporech, které se týkají budování či uspořádání Ruska („obustrojstvo“; právě toto slovo ostatně použil ve svém pozdním traktátu z roku 1990 Kak nam obustroit Rossiju Alexandr Solženicyn, bohužel poněkud iluzorně). Autorka začíná ještě předděkabristickým obdobím, samožrejmě, jak jinak, než u Michaila Speranského, ale mohla také jako Polka uvést četné Poláky počátku vlády Alexandra I., jak jsme o nich psali v souvislosti s polemikami Franka Wollmana s Poláky o tom, kdo Evropě nasugeroval panslavistický mýtus [POSPÍŠIL 2016]. Poněkud chudě tu vyhlížejí koncepce děkabristů, tak košaté a rozrůzněné, sám Puškin by se tu měl objevit na desítkách stran, nejen raný a zralý Turgeněv. ${ }^{4} \mathrm{~V}$ dalších partiích, $\mathrm{v}$ jejichž středu stojí opět Ivan Turgeněv, sklouzává autorka $\mathrm{k}$ tomu, co se objevuje již na samém počátku, tedy $\mathrm{k}$ převyprávění syžetu a uzlových momentů polemiky, tedy sporů $\mathrm{v}$ různých obdobích, zejména $\mathrm{v}$ románech spojených s reformními snahami 6o. let 19. století, stejně jako v reflexi zkušenosti dekády následující (s. 167n.). Poněkud podstatnější jsou její výklady o sporech konce 19. století, jak se projevují v ruské literatuře realismu, naturalismu a moderny. Bohužel právě počátek 2o. století je výrazně redukován, uváděná zjištění mohla být více rozvinuta, aby se ukázalo, že spory „klasikư“ měly své, byt často polemické pokračování. V závěru autorka správně poznamenala, že sama poetika sporu měnila i podobu literatury, ale čekat od toho nějaké reálné řešení ruských problémů již překračuje rámec literární vědy a jde spíše k sociologii, sociální psychologii a politologii, kam autorka - alespoň soudě podle způsobu podání - nesměřuje. Čekat od literatury nějaká řešení společenská je utopické: ona jen provokuje, naznačuje, ukazuje, odhaluje, spíše rozvrací, než sceluje koncepčně se tyto spory prezentované v literatuře řeší na jiné ploše. Nicméně ruská

2 Viz naše knížky Ruská románová kronika [POSPÍŠIL 1983], Labyrint kroniky [POSPÍŠIL 1986a], Proti proudu (Studie o N. S. Leskovovi) [POSPÍŠIL 1992a] a Rozpětí žánru [POSPÍŠIL 1992b].

3 Jisté korekce sem nověji vnáší i kniha Vitalije Machlina, viz naši recenzi: [POSPÍŠIL 2015)].

4 Viz naši stat' [POSPÍŠIL 1986b]; také v knize [POSPÍŠIL 1999]. 
literatura na jedné straně reflektovala společenskou situaci, na straně druhé tyto spory provokovaly i změny společenské - v tom je síla ruského subjektivismu a také specifikum ruského románu, který nechce svět jen reflektovat, ale i měnit - odtud jeho blízkost tehdejšímu marxismu.

Kniha Barbary Olaszek je intelektuálně silná, její výklad je koncentrovaný na několik autorů a děl, což je výhoda, ale současně i slabina, nebot’ se tím materiál značně ochuzuje a působí místy schematicky, ale rozsah problému je tak velký, že jej nelze spoutat do jedné monografie: toho si byla autorka asi vědoma a obávala se asi právě výkladové disperze. Otázkou zůstává, zda je spor tak významný právě jen v ruské literatuře, jak se snaží od počátku ukázat, zda se spor nejeví stejně významný i jinde v literaturách slovanských i obecněji evropských či světových: sama zkušenost polské literatury by to pravděpodobně ukázala podle mého soudu přesvědčivě. To je další problém knihy právem soustředěné na ruský materiál bez většího komparativního přesahu, hodně „ruské“ kladení otázek a stavění problémových okruhů, což bývá u nás neruských rusistů někdy obvyklé. Nicméně kniha ve svém celku ukazuje ruskou literaturu klasického období z jiného zorného úhlu, ostře, v souvislosti se společenskými procesy, začleňuje literaturu do sociálního prostoru a také implicitně manifestuje proměny poetiky v závislosti na "anatomii“ a "fyziologii“ sporu jako jádru ruského písemnictví ve velkém časovém oblouku, v podstatě od konce 18. po začátek 20. století: zajímavé by bylo toto téma protrahovat k sovětskému období, přes literaturu emigrace k postmodernismu a postpostmodernismu. Což, jak lze doufat, autorka může doplnit v dalších očekávaných publikacích.

Ivo Pospíšil

\section{Literatura:}

OLASZEK, B. (2016): Russkije spory v chudožestvennom diskurse klassikov. Łódź. POSPÍŠIL, I. (1983): Ruská románová kronika. Brno.

POSPÍŠIL, I. (1986a): Labyrint kroniky. Brno.

POSPÍŠIL, I. (1986b): Puškinův „, fohn Tanner“ - jeho kontext, smysl a funkce. Československá rusistika, 1986, č. 3, s. 106-111.

POSPÍŠIL, I. (1992a): Proti proudu (Studie o N. S. Leskovovi). Brno.

POSPÍŠIL, I. (1992b): Rozpětí žánru. Brno.

POSPÍŠIL, I. (1999): Na výspě Evropy. Skici a meditace k 2oo. výročí narození A. S. Puškina. Brno.

POSPÍŠIL, I. (2015): Hledáni „velkého času“ Michaila Bachtina (Machlin, V. L.: Bol’šoje

vremja: Podstupy k myšleniju M. M. Bachtina. Opuscula Slavica Sedlcensia, tom VIII. 
Redakcja tomu Roman Mnich i Roman Bobryk. Siedlce: Uniwersytet Przyrodniczo-Humanistyczny w Siedlcach, 2015). Novaja rusistika, 2015, č. 2, s. 76-81.

POSPÍŠIL, I. (2016): Frank Voll'man i jego polemiki o panslavizme. In: CHYRA-ROLICZ, Z, ROKOSZ, T. (eds): Panslawizm wczoraj, dziś, jutro. Siedlce, s. 147-160. POVARIN, S. I. (2009): O teorii i praktike spora. Moskva.

STARYGINA, N. N (2003): Russkij polemičeskij roman 1860-1870-ch godov v situacii filosofsko-religioznoj polemiki. Moskva.

https://doi.org/10.5817/NR2018-2-8

\section{Solženicyn komplexně: tvorba, Polsko a emigrace}

DĄBROWSKA, M., GŁUSZKOWSKI, P. (eds): Aleksander Sotżenicyn i rosyjska emigracja. Warszawa-Toruń: Instytut Rusycystyki Uniwersytetu Warsawskiego, 2018. ISBN 978-83-64869-21-1.

Na rozdíl od 60.-90. let 20. století zájem o osobnost Alexandra Solženicyna pohasl. Alespoň pokud jde o zájem povrchový, k němuž radím politické konotace nositele Nobelovy ceny. Na druhé straně je tu tedy šance zabývat se tím, čím Solženicyn vlastně začal, byt by to byla jen obvyklá maska ruských literátů směřujících od literatury řadou přesahů $\mathrm{k}$ politice, filozofii, dokonce kosmologii: jeho téma bylo výsostně politické, ale současně se autor ukázal jako umělec, jenž suverénně zvládl nejen drobnější útvary povídky a novely, ale také rozlehlou plochu románu, včetně historicky artikulovaného: jejich publicistické podoby vtělil do traktátů 9o. let 20. století, když se vrátil do Ruska a cestoval po něm, většinou nepochopen nebo posuzován značně kriticky až negativisticky. Snad tedy nastala doba pojmout Solženicyna opět sine ira et studio s koncentrací na uměleckou podstatu jeho díla, byt i víme, že to nobelovský výbor zajímalo asi nejméně. Mezinárodní konference a publikační výstupy poslední doby o tom svědčí snad právě proto, že autorova módnost už pominula, a zůstalo tak jen to, co je skutečně hodnotné. Možná toho nebude tolik, jak se dříve myslelo, ale to, co zatím v našem povědomí zůstává, je významné a patrně i nedoceněné.

Na konci 8o. a na počátku 9o. let minulého století, kdy se Solženicyn začal vydávat v SSSR a zemích jeho tehdejších satelitů, se o něm v Bratislavě konala konference pod záštitou děkana Filozofické fakulty Univerzity Komenského, rusisty Ivana Slimáka (1931-1996), s nímž jsem předtím domlouval brněnskou účast - bylo to v roce 1990. Slimák tehdy doufal, že se jí zúčastní i sám Solženicyn, jehož pozval, ale to se nestalo. Možná to bylo i štěstí (i když pro Solženicyna - vzhledem $\mathrm{k}$ jeho velkoruství - byly asi pohyby v bývalých sovětských satelitech pod jeho rozlišovací schopnost), protože 